\title{
Meningkatkan Membaca Menulis Melalui Teknik SAS Kelas 3 MI No. 1 Pancor Lombok Timur
}

\author{
M. Deni Siregar ${ }^{1}$, Dukha Yunitasari ${ }^{2}$ \\ Universitas Hamzanwadi ${ }^{1,2}$ \\ muhammaddenisiregar@gmail.com ${ }^{1}$,dukha.yunitasari@gmail.com²
}

\begin{abstract}
Abstrak
Penelitian ini bertujuan untuk mengetahui pengaruh teknik $S A S$ dalam meningkatkan membaca dan menulis permulaan pada siswa kelas 3 MI No 1 Pancor di lombok timur. Metode yang digunakan dalam penelitian ini adalah metode Penelitian Tindakan Kelas (PTK). Penelitian Tindakan Kelas ini dilaksanakan dalam dua siklus, setiap siklus terdiri dari empat tahap, yaitu perencanaan, tindakan, pengamatan (observasi), dan refleksi. Alat yang digunakan untuk mengukur dan mengetahui data adalah menggunakan lembar observasi, tes dan catatan lapangan. Lembar observasi digunakan untuk mengetahui aktivitas membaca dan menulis siswa pada buku teks yang disediakan, tes dilakukan setiap akhir siklus untuk mengetahui peningkatan kemampuan membaca dan menulis dengan teknik SAS. Berdasarkan hasil observasi pembelajaran baik pada siklus I maupun siklus II siswa sudah mamapu membaca dan menulis dengan cepat. Hasil tes dari pembelajaran siklus I diketahui 8 dari 30 orang siswa belum membaca cepat. Pada hasil pembelajaran siklus II 30 dari 30 orang semuanya sudah bisa membaca dengan cepat. Dapat disimpulkan bahwa kemampuan membaca dan menulis dapat ditingkatkan melalui teknik $S A S$.
\end{abstract}

Kata kunci : Membaca Cepat, Teknik SAS 


\section{PENDAHULUAN}

Membaca dan menulis merupakan sumber ilmu yang paling mudah di rasakan oleh manusia, karena dengan memlalui membaca seseorang bisa memiliki pengalaman dan informasi tentang ilmu yang terdapat dalam buku teks yang tersampaikan oleh penulis. Ide dan gagasan dapat menginsfirasi setiap pembaca ketika yang dibaca itu adalah teks yang dapat difahami dan dimaknai. Di sekolah ketika kita dibangku sekolah, kita diajarkan oleh ibu dan bapak guru untuk memahami tentang membaca cepat yaitu dengan memberikan praktek langsung dengan teman sebangku. Namun saat dulu kita hanya sekedar mengetahui dan mempraktekan karena arahan guru. Disini yang saya inginkan, kita bukan sekedar tahu, tapi harus paham untuk apa teknik membaca dan menulis dipraktekan, sehingga kita mampu mengaplikasikan membaca cepat pada saat kita membutuhkannya. membaca dan menulis adalah kecakapan atau kemahiran dalam membaca dan memahami teks bacaan dengan tingkat tinggi. Artinya dalam membaca cepat, seseorang harus membaca dengan mengutamakan kecepatan dan sekaligus mampu memahami teks yang ia baca minimal 70\%. Maka jika seseorang mampu membaca lebih banyak kata dalam waktu singkat, berarti teknik membaca cepatnya semakin baik. Dalam membaca dan menulis akan disesuaikan dengan tingkat usia/intelektual seseorang.

Penelitian ini akan memfokuskan proses membaca dan menulis dengan teknik SAS di kelas 3 MI No 1 Pancor Lombok timur, hal di karenakan peneliti ingi mengetahu sejauh mana pengaruh tingkat kemampuan siswa membaca dan menulis melalui metode SAS.

Membaca dan menulis sebagai salah satu aspek dari empat keterampilan berbahasa, memegang peranan penting dalam pengajaran bahasa indonesia. Dikatakan penting karena, selain pelajaran menyimak, berbicara, dan menulis.Keterampilan membaca adalah salah satu alat yang sangat ampuh untuk memperoleh berbagai macam informasi tertentu, termasuk ilmu pengetahuan dan teknologi.Oleh karena itu, membaca adalah kebutuhan dasar bagi masyarakat maju.Demikian pula dalam dunia pendidikan, peranan membaca sangat berpengaruh terhadap prestasi siswa.Hal ini dapat dibuktikan bahwa semakin tinggi pemahaman siswa, semakin tinggi pula pengetahuan yang dimilikinya.Dengan demikian minat 
baca dan kemampuan membaca siswa perlu ditumbuhkan sedini mungkin, agar siswa dapat memahami peranan dan fungsi membaca.Baik alat komunikasi maupun sebagai alat belajar untuk mengembangkan pengetahuan dan memperluas cakrawala keterampilannya. Dapat dikatakan bahwa anak didik yang mempunyai tingkat kemampuan membaca dan menulis yang lebih tinggi akan lebih mudah memperoleh ilmu pengetahuan dan teknologi yang tertuang dalam media cetak atau media tulis. Berdasarkan hal tersebut, pemerintah telah melakukan upaya untuk membudayakan kebiasaan membaca di kalangan siswa maupun kalangan masyarakat luar, misalnya dengan mendirikan perpustakaan sekolah maupun perpustakaan umum, mengadakan pameran buku, dan seminar yang bertujuan untuk menggairahkan minat membaca dan menulis siswa dan masyarakat pada umumnya.

Pada kelas seusia sekolah dasar di banyak hal yang harus dikuasai guru dalam memperlancar siswa dalam membaca, diantaranya metode atau strategi membaca yang di lakukan guru pada siswa. Siswa akan bisa termotivasi membaca jika metodenya tepat, di sekolah dasar yang ada di sekitar lombok timur ada beberapa siswa yang kemampuan membacanya sangat rendah bila dibandingkan temannya, sehingga peneliti mecoba menggunakan metode $S A S$ dalam menuntaskan rendahnya kemampuan membaca cepat pada anak sekolah dasar. Metode SAS merupakan kemampuan membaca cepat secara sepintas untuk menemukan gagasan atau ide pokok keseluruhan teks.

Membaca dan menulis merupakan suatu teknik dalam membaca untuk bisa mendapatkan informasi dengan cara langsung ke masalah ataupun fakta yang dicari untuk ditulis dengan baik sesuai dengan dengan apa yang di dapatkan melalui membaca. Metode SAS merupakan singkatan dari "Struktural Analitik Sintetik". Metode SAS merupakan salah satu jenis metode yang biasa digunakan untuk proses pembelajaran menulis membaca permulaan bagi siswa pemula. Dalam proses operasionalnya metode SAS mempunyai langkah langkah berlandaskan operasional dengan urutan : Struktural menampilkan keseluruhan, guru menampilkan sebuah kalimat pada anak, analitik melakukan proses penguraian: anak daiajak untuk megenal konsep kata dan mulai menganalisis kalimat menjadi kata, kata menjadi suku kata dan suku kata menjadi huruf, sintetik melakukan penggabungan kembali 
kepada bentuk Struktural semula, setelah kalimat diuraikan dari huruf dirangkai menjadi suku kata, suku kata menjadi kata dan kata menjadi kalimat semula.

Ini merupakan salah satu metode membaca dan menulis yang dilakukan dengan cara membaca didalam hati. Dengan membaca dan menulis ini anda akan memperoleh informasi yang maksimal dalam waktu yang sesingkat-singkatnya dan juga dengan tingkat pemahaman isi bacaan yang tinggi juga. Adapun Hal-hal yang perlu untuk diperhatikan dalam membaca dan menulis ini ialah dengan : Jangan membaca kata demi kata. Biasakan dalam membaca itu per kelompok kata demi kelompok kata, Jangan mengulangi kata atau kalimat yang sudah dibaca, Jangan terlalu lama berhenti di awal baris atau pun kalimat karena akan memutuskan hubungan makna antarkalimat maupun antarparagraf, Carilah kata kunci yang menjadi tanda awal terdapatnya sebuah gagasan utama pada sebuah kalimat, Abaikan juga kata-kata lugas yang sifatnya itu berulang-ulang, misalnya kepada, yang, di, dari, dan lain sebagainya.

Membaca dan menulis tentu memiliki suatu tujuan, tujuan dalam membaca dan menulis ini adalah untuk meminimalisir penggunaan waktu agar dapat waktu dalam membaca itu relatif singkat dan kita tetap mampu untuk mendapatkan hasil serta juga memahami bacaan yang kita baca. Kenapa sih membaca cepat itu penting? Karena hampir seluruh informasi yang kita cari atau yang kita dapat itu berasal dari buku-buku, koran, majalah bahkan juga internet itu menggunakan teks dalam menyampaikan informasinya.Teknik membaca cepat SAS ialah suatu teknik untuk dapat mencari gagasan pokok atau hal-hal penting lainnya yang ada di dalam bacaan. SAS terdapat dapat atau bisa dilakukan apabila : Ingin mengenali topik bacaan, Ingin melakukan suatu penyegaran akan apa yang pernah dibaca, Ingin mendapatkan bagian penting dari suatu bacaan tanpa membaca keseluruhan, Ingin mengetahui pendapat seseorang dengan secara garis besar atau umum saja. Metode SAS adalah metode pembelajaran membaca yang dimulai dengan langkah bercerita sambil menunjukkan gambar pendukung. Setelah itu siswa diajak untuk membaca gambar tersebut, yang dilanjutkan dengan membaca kalimat yang ada dibawah gambar. Selanjutnya gambar dilepas atau diambil dan tinggal lah kalimatnya. Siswa berlatih membaca kalimat tanpa bantuan gambar (proses struktural). Kalimat tersebut lalu dianalisis menjadi kata, suku kata, huruf-huruf (proses analitik). Langkah terakhir 
adalah menggabungkan kembali huruf-huruf menjadi suku kata, suku kata menjadi kata, dan kata-kata menjadi kalimat (proses sintetik).

Beberapa situasi yang menuntut penggunaan SAS ini antara lain ialah: memeriksa sebuah bab didalam sebuah buku, sebelum memperlajarinya dengan secara serius agar dapat memperoleh sebuah gagasan mengenai cakupan secara umum bab tersebut, menyampel beberapa halaman novel atau juga karya tulis jenis lain untuk dapat menentukan apakah karya tulis itu adalah bacaan yang bernilai, memeriksa dengan secara cepat sebuah artikel tentang isu kontroversial dalam menemukan pandangan pengarang, tanpa harus memperhatikan argumen pengarang yang spesifik, memeriksa juga bahan bacaan dalam menilai apakah bacaan tersebut mengandung jenis informasi yang sedang dicari, meneliti juga bahan bacaan dalam menentukan apakah bacaan tersebut bisa dipahami ataukah terlalu sulit. Langkahlangkah membaca SAS: membuat pertanyaan tentang apa yang akan kita cari dari suatu buku, Telusuri daftar isi atau pun kata pengantar, apakah informasi yang kita butuhkan itu ada didalam bacaan tersebut, focus, telusuri dengan kecepatan tinggi tiap-tiap paragraf atau juga subbab, berhentilah saat anda sudah merasa menemukan apa yang anda cari, bacalah dengan kecepatan normal, serta juga pahami dengan baik apa yang anda cari.

\section{METODE PENELITIAN}

Metode penelitian yang dignakan dalam penelitian ini adalah penelitian tindakan kelas yang imaksudkan untuk memperbaiki pembelajaran di kelas. Penelitian ini merupakan salah satu upaya guru atau praktisi dalam bentuk berbagai kegiatan yang dilakukan untuk memperbaiki dan atau meningkatkan mutu pembelajaran di kelas. PTK dapat diartikan sebagai proses pengkajian masalah pembelajaran di dalam kelas melalui refleksi diri dalam upaya untuk memecahkan masalah tersebut dengan cara melakukan berbagai tindakan yang terencana dalam situasi nyata serta menganalisis setiap pengaruh dari perlakuan tersebut. PTK merupakan salah satu publikasi ilmiah dalam konteks pengembangan profesi guru secara berkelanjutan yang ditujukan untuk perbaikan dan peningkatan mutu proses dan hasil pembelajaran atau mutu pendidikan pada umumnya. PTK ini cocok dilakukan oleh guru karena prosenya praktis. Dalam penelitian tindakan kelas ini, peneliti merencanakan pelaksanaan melalui dua siklus yaitu siklus I dan siklus II. 
Setiap siklus terdiri atas empat tahap, yaitu perencanaan, tindakan, observasi, dan refleksi. Penelitian ini dilaksanakan di kelas 3 MI no. 1 Panco. Subjek dalam penelitian ini adalah siswa di kelas 3 MI No 1 Pancor Lombok timur, yang berjumlah 30 siswa. Guru kelas terlibat dalam penelitian ini sebagai observer (pengamat) jalannya penelitian. Selain itu observer juga mengamati, menilai proses membaca.

Teknik pengumpulan data pada proses penelitian ini adalah lembar observasi, tes membaca, catatan lapangan, adapaun tekni alaisis data menggunakan : menganalisis data hasil observasi terhadap pelaksanaan tindakan setiap siklus dengan teknik analisis deskriptif kualitatif, yaitu analisis yang hanya menggunakan paparan sederhana. Menentukan rata-rata dari seluruh siswa yang mengikuti tes. Tingkat keberhasilan siswa berdasarkan skor tes yang diperoleh ditetapkan dalam nilai dengan menggunakan rumus sebagai berikut :

$$
N I L A I=\frac{\text { SKOR SISWA }}{\text { SKOR MAKSIMAL }} \times 100
$$

\section{HASIL DAN PEMBAHASAN}

Setelah siswa arahan guru dalam menjalankan proses membaca dan menulis dengan menggunakan teknik $S A S$ melewati dua siklus sebagai alat untuk mengetahu sejauh mana pengarus teknik $S A S$ dalam meningkatkan kemampuan membaca di kelas 3 MI No 1 Pancor Lombok timur. Membaca dan menulis sebagai salah satu aspek dari empat keterampilan berbahasa, memegang peranan penting dalam pengajaran bahasa indonesia. Dikatakan penting karena, selain pelajaran menyimak, berbicara, dan menulis. Metode SAS adalah sebuah metode yang memulai pengajaran dengan menunjukan struktur kalimat secara utuh dahulu, lalu kalimat utuh itu dianalisis dan pada akhirnya dikembalikan lagi pada bentuk semula dan salah satu alat yang sangat ampuh untuk memperoleh berbagai macam informasi tertentu, termasuk ilmu pengetahuan dan teknologi. Oleh karena itu, membaca adalah kebutuhan dasar bagi masyarakat maju. Demikian pula dalam dunia pendidikan, peranan membaca sangat berpengaruh terhadap prestasi siswa. Hal ini dapat dibuktikan bahwa semakin tinggi pemahaman siswa, semakin tinggi pula pengetahuan yang dimilikinya.Dengan demikian minat baca dan kemampuan membaca siswa perlu ditumbuhkan sedini mungkin, agar siswa dapat memahami peranan dan fungsi membaca. Baik alat komunikasi maupun sebagai alat belajar 
untuk mengembangkan pengetahuan dan memperluas cakrawala keterampilannya. Dapat dikatakan bahwa anak didik yang mempunyai tingkat kemampuan membaca yang lebih tinggi akan lebih mudah memperoleh ilmu pengetahuan dan teknologi yang tertuang dalam media cetak atau media tulis. Berdasarkan hal tersebut, pemerintah telah melakukan upaya untuk membudayakan kebiasaan membaca di kalangan siswa maupun kalangan masyarakat luar, misalnya dengan mendirikan perpustakaan sekolah maupun perpustakaan umum, mengadakan pameran buku, dan seminar yang bertujuan untuk menggairahkan minat baca siswa dan masyarakat pada umumnya.

Siswa di kelas 3 MI No 1 Pancor Lombok timur, memiliki kemampuan membaca dan menulis dengan teknik $S A S$ dalam proses belajar dapat meningkatkan kemampuan membaca dan menulis. Peningkatan kemampuan membaca cepat dalam kegiatan belajar mengajar pokok peajaran membaca dengan teknik $S A S$ dapat memberikan pengalaman baru kepada siswa dalam belajar membaca. Proses pembelajaran membaca cepat dapat menghilangkan kejenuhan membaca pada siswa karena dengan menggunakan teknik $S A S$ siswa dapat memperoleh pengetahuan dan informasi yang diperlukan dengan cepat dan tepat, sehingga tidak menimbulkan kejenuhan pada saat belajar, kemudian siswa bisa menggunakan waktunya dengan baik untuk membaca karena dengan banyak membaca, maka banyak pula pengetahuan dan informasi yang diperoleh dengan cepat, hal tersebut dapat meningkatkan keinginan siswa untuk membaca. Pengaruh peningkatan keterampilan membaca cepat dengan teknik $S A S$ terhadap kemampuan membaca cepat siswa kelas 3 MI No 1 Pancor Lombok timur sangat berpengaruh, hal ini dapat terbukti dengan hasil tes membaca membaca cepat dengan teknik SAS yang selalu meningkat dari mulai skor rata-rata 67,75 pada siklus I dan 87,57 pada siklus II Peningkatan kemampuan membaca cepat dengan teknik $S A S$ dalam kegiatan belajar mengajar dapat meningkatkan kemampuan membaca siswa, hal ini terbukti dengan meningkatnya aktivitas siswa kelas 3 MI No 1 Pancor Lombok timur mulai dari siklus I ke siklus II yang diukur melalui lembar observasi aktivitas siswa dan hasil tes setiap siklus. Berdasarkan hasil tes kemampuan membaca dan menulis dengan teknik SAS siswa kelas 3 MI No 1 Pancor Lombok timur terlihat $80 \%$ siswa bisa membaca dan menulis dengan cepat tanpa terbata-bata. 


\section{SIMPULAN}

Berdasarkan pembahasan diatas dapat dikatakan bahwa Siswa di kelas $3 \mathrm{MI}$ No 1 Pancor Lombok timur, memiliki kemampuan membaca dan menulis dengan teknik SAS dalam proses belajar dapat meningkatkan kemampuan membaca cepat. Peningkatan kemampuan membaca cepat dalam kegiatan belajar mengajar pokok pelajaran membaca dengan teknik $S A S$ dapat memberikan pengalaman baru kepada siswa dalam belajar membaca. Proses pembelajaran membaca cepat dapat menghilangkan kejenuhan membaca pada siswa karena dengan menggunakan teknik SAS siswa dapat memperoleh pengetahuan dan informasi yang diperlukan dengan cepat dan tepat, sehingga tidak menimbulkan kejenuhan pada saat belajar, kemudian siswa bisa menggunakan waktunya dengan baik untuk membaca dan menulis karena dengan banyak membaca dan menulis, maka banyak pula pengetahuan dan informasi yang diperoleh dengan cepat, hal tersebut dapat meningkatkan keinginan siswa untuk membaca dan menulis. Pengaruh peningkatan keterampilan membaca cepat dengan teknik $S A S$ terhadap kemampuan membaca dan menulis siswa kelas 3 MI No 1 Pancor Lombok timur sangat berpengaruh, hal ini dapat terbukti dengan hasil tes membaca membaca dan menulis dengan teknik SAS yang selalu meningkat dari mulai skor rata-rata 67,75 pada siklus I dan 87,57 pada siklus II.

\section{DAFTAR PUSTAKA}

Soedarsono.1993. Sistem Membaca Cepat dan Efektif. Jakarta: Gramedia Pustaka Utama.

Tampubolon, D.P. 1990. Kemampuan Membaca Teknik Membaca Efektif dan Efisien.Bandung : Angkasa.

Tarigan, Henry Guntur. 1983. Membaca Ekspresif. Bandung: Angkasa.

Tarigan, Henry Guntur. 1979. Membaca Sebagai Suatu Keterampilan Berbahasa.

Wiryodijoyo, Suwarsono. 1989. Membaca Strategi Pengantar dan Tekniknya. Jakarta : Depdikbud. 